\title{
THE IMPACT OF RELIGION ON A SECULAR STATE: THE NIGERIAN EXPERIENCE
}

\author{
Momoh Lawani Yesufu \\ Former Study Group Director/Senior Research Fellow \\ National Institute for Policy and Strategic Studies, Kuru, Nigeria \\ lawani.yesufu2013@gmail.com
}

\section{ABSTRACT}

Nigeria, in her 55 years of nationhood, is the most populated black nation in the world. She has to her credit a written Constitution being operated for the effective democratic governance of her population, comprising peoples of different religious freedom and cultural backgrounds. In Nigeria, Christianity, Islam and traditional religions are most widely practised. Religion is a faith-based process that is capable of impacting on governance and the behavioural attitudes of every believer. Nigeria is a secular state. Since interaction theory provides avenues for exchanges of nonmaterial goods and materials, we used this theory as the most appropriate in the conduct of this study. This article explores the impact of religion on Nigerians living within a secular state.

Keywords: Nigeria; constitution; religion; security; colonialism; secularism; secular state; reward; interaction theory

\section{INTRODUCTION}

This study explores the impact of religion on certain aspects of Nigerians living within a secular state. Such impact is argued within the concept of interaction theory, which provides avenues for social behaviour that can be used to interpret human behaviour. As interaction provides avenues for exchanges of non-material goods and materials, we used this theory as the most appropriate in the conduct of this study. Because this theme will specifically focus on the Nigerians' experience, it

\section{UNISA}


necessitates the inclusion of a brief background about the country's constitutional history.

Nigeria was amalgamated by the British in 1914, granted political independence on 1 October 1960 and given republican status on 1 October 1963. The country has celebrated her 55 th year of independence first under parliamentary democracy broken by military rule and then followed by a Presidential capitalist system of democracy since 1999. Nigeria is a highly populated nation whose political attempts aimed at effective governance, have led to frequent re-drafting of her written Constitution which cannot be said to be a perfect document even after five amended Constitutions $(1960,1963,1979,1989,1999)$, each one making Nigeria more of a secular state. It is self-evident that these constitutional drafting processes have given Nigerians some experience in the constitution-making process. In all these drafted Nigerian Constitutions, the position of law is that religious belief is not to influence any public or government decisions. However, interaction within religious groups of Islamic faith and Christian faith did indeed show evidence of one religion trying to outdo the faith of the other through aggressive conversion into political association and religion practice (Kukah 1993; Usman 1987).

According to statistical calculations during 2005, Nigeria currently has a projected population of 165731525 million $^{1}$, consisting of 373 identifiable ethnic groups with rich cultural diversity (National Bureau of Statistics 2005, 5). Another source, however, estimates Nigeria's population for 2013 at 173.6 million; thus representing 15.4 per cent of the entire African population of 1.1298 billion (AfDB Statistics Pocketbook 2014, 97).

This article contends that the end result of such a prolonged constitutional process is that it has turned Nigeria into a secular state. Conceptually, constitutionalism is a process of making and producing formal principles and laws into a comprehensive document needed to regulate the behaviour of government or any institution. It also entails an act of producing a legal document describing a formal system of government, binding on an entire country and compelling adherence to its principles. This latter concept is what is adopted for this paper. The operating Federal Republic of Nigeria 1999 Constitution is a product of constitutionalism based on English liberal thought. The framework of the Constitution provides all Nigerians with an organised way by which to argue about their future. For instance, it provides the right to freedom of worship, freedom of association, and the right to life, among others. Through content analysis of the 1999 Constitution, this study observed the word 'religion' being mentioned 74 times. For this paper, in focusing on the impact of religion, we shall examine the themes of: 1) interactionism in religion practice; 2) religious freedom and politics; 3) impact on Nigerian military institutions; 4) influence of education and secularism; 5) external factor influence; and then 6) end the paper with concluding remarks. 


\section{INTERACTIONISM IN RELIGION PRACTICE IN NIGERIA}

Interactionism is social behaviour that relates an individual's action to possible costreward implications. According to the Free Dictionary (https://en.wikipedia.org/ wiki/Interactionism), it is a theoretical perspective that derives social processes (such as conflict, cooperation, identity formation) from human interaction. It is the study of how individuals act within society. It is, therefore, understandable that in a secular state like Nigeria it is not unusual for people of different religious backgrounds to relate to one another wherever it will be more rewarding to them than living in isolation. Blau (1969) describes reward to mean a positive reinforcement in any form that gratifies a person's needs. For example, religion is faith-based reward that satisfies an individual's mode of worship, freedom of association and room for interaction with others, thereby satisfying some of the human needs. Coser and Rosenberg (1969) trace the origin of interactionism to the work of Simmel, Malinowski, Homans and Blau. They also observe that by Malinowski's conviction, basic obligations and rights must be understood in terms of reciprocal obligations which the members of society have towards each other. As people worship in groups they interact with one another and conform to common doctrine.

The Nigerian Constitution pre-supposes that an individual has freedom to practise religion of his or her choice without government interference. This is where secularism comes into play. Secularism is a legal position in the supreme law of Nigeria, stating that religious belief should not influence any public and/ or governmental decisions. In other words, secularism is a documented position in a Constitution relating to political belief in the separation of religion and state. While people are allowed to practise whatever they believe in as their religion, the government must not allow that to influence public policy. Religion is the service and worship of God or gods. The word 'religion', which was first used in the 13th century, is Latin in its origin. From a sociologist perspective, the society creates religion as an instrument in moulding, controlling and directing societal thinking and behaviour (Durkheim 1915, 207-211). Durkheim's theory of religion further sees God as a personification of the society, where all the laws and commandments of God are demanded from all members of the society for societal self-preservation. By this concept, a country ought to adopt a state religion to be in a position to demand good religious conduct from all members of her society. This latter view is the adopted meaning of religion in this paper.

As Maykovich (1980) explains, interaction theory assumes interpretative approach where the individual interprets the situation and thus determines his or her behaviour accordingly. Such behaviour does not appear to be a product of adherence to normative orientation to macro social structure (functionalism), he argues. Secularism in the Constitution could have been borne out of previous experiences encountered for either non-inclusion, or viewed from the population's diversity in beliefs, culture and societal self-preservation. It could also have been included in the 
Constitution in fulfilment of human needs which generally arise out of the existence of concrete histories of each society, and to help colonial power subdue the people through religious conversion. Danbatta (1956) was alarmed by the inclusion of religion as a non-governmental affair. He says: 'By writing a clause about religious freedom in our Constitution, we are causing the elimination of that freedom, inviting unrest.' Events that followed thereafter in the 55 years of Nigerian independence tend to confirm this alarm.

\section{RELIGIOUS FREEDOM AND POLITICS}

As a young boy born in the southern part of Nigeria, I grew up to find Muslims and Christians living together within the same community. However, as I grew up into adulthood the central government in practice changed its policy of non-interference in religious matters to that of regulating the number of people performing Islamic and Christian rites inside and outside Nigeria. This check on religious freedom came out of trying to have political control of the citizens by using religion as a weapon; contrary to the constitutional provision of non-interference in the religious affairs of the people. In the southern parts of Nigeria, this situation changed the way that families and governments think. They now also had to create institutions to control religious affairs, while the ruling class in the north of Nigeria had to be seriously subsumed into the mould of the Islamic faith as a way of protecting her Islamic and political interests (Kukah 1993, 42). In particular, they had (and continue to have) Arab money flowing into northern Nigeria. This made it easy for the ruling class to set up Jamaatu Nasril Islam (JNI) for the propagation of Islam in northern Nigeria, and to embark on an aggressive conversion of non-Muslims to Islam.

To counter such action, led to another reaction; this time from those within the Christian faith who formed the Northern Christian Association (NCA) to shield the Christians (who were in the minority in the north) from the impact of an Islamic conversion campaign. The NCA also had the purpose to address grievances against the excesses of the state in using JNI to negotiate its way to retain political power and to propagate Islam. Kukah $(1993,100)$ rightly observes that to the ruling classes 'some Muslims are more Muslims than others' and for survival generally some Christians may want to become Muslims or adopt the Hausa culture, thereby gaining access into certain social relations or have the ability to understand northern interests and know how to help build them. With all these threats, the NCA was not automatically going to get the sympathy of the Christians in the south. So in 1964, the NCA had to strengthen its position by changing its name to Christian Association of Nigeria (CAN), covering all Christians in Nigeria as a way of providing a platform for a national association capable of providing avenues for common interest, enlistment of strong bargaining power, generating more resources, and establishing a uniting bloc. 
The imposition of State religion first existed before the advent of the British colonialists, who invariably institutionalised religion practice in government business using chiefs and Emirs to achieve their political interests. The chiefs and Emirs who stood as religious leaders, also operated as political leaders. Any disobedience from anybody outside the ruling classes was seen as economic, religious, and political threat. 'The British guaranteed that they will not interfere with the Muslim religion, but the establishment of Anglo-Fulani rule meant that the ideals of Islamic law and practice had to be bent here and there' to favour both the emirate ruling classes and the British interests (Kukah 1993, 115). This is perhaps how the patterns of demographic distribution of Christian and Muslim populations became products of Christian missionaries and the Arabs Jihadists. The Jihadists were the first to colonise the respective regions that made up Nigeria. When the British came, they capitalised on the same religious divide to rule the entire territory. Such colonial method of governance was called indirect rule in which, even though every religion comes with its symbols, belief, practices, institutions, policies and organisations, certain situations were bent to accommodate economic and political ambitions of the few Nigerians and British actors. Getting used to such modified practices, symbols and beliefs changed the orientation of individuals and families. This had a huge impact on the individuals and their families.

Each religion follower from north to south (as earlier noted) was able to defend his/her position in the social political order through JNI and CAN respectively. These two associations have over the years welded powers to protect and defend their members and reduce divisions within various groups. Consequently, the generality of the people started re-ordering their direction of cultural realm as well as fixing their social relations and securing their political spheres. The details of the religious intrigues of this era are outside of our scope. This paper can only recap that the colonialists merely saw adherents to Christianity and Islamic religion as products of the processes of modernisation, social mobility and constant orientation which contributed to the achievement of their objectives.

CAN and JNI as religious tools have grown into such strong associations over the years that they are able to defend their religions, which the Nigerian 1999 Constitution, Section 10 clearly guarantees through freedom of association. The Constitution exemplifies the section as follows: 'The Government of the Federation or of a State shall not adopt any religion as a State Religion.' This means there is prohibition of State Religion whose authority revolves around the term 'secularism' of the Nigerian State, and by which it is further implied under Section 1(1): 'This Constitution is Supreme and its provisions shall have binding force on all authorities and persons throughout the Federal Republic of Nigeria.' As a way of avoiding ambiguity, Section 1(3) of the Constitution further states that: 'If any other law is inconsistent with the provisions of this Constitution, this Constitution shall prevail, and that other law shall to extent of the inconsistency be void.' This means rather 
than the adoption of State religion in some of the states of the federation, working on bills to amend the relevant areas of the Constitution would protect peace rather than trying to erode the separation of religion issues from state policies. For instance, the Holy Qur'an affirms that religious worship should be left for the individual, since the right path is distinct from the wrong path. It says:

There is no compulsion in religion. Verily, the Right Path has become distinct from the wrong path. Whoever disbelieves in 'Taghut' [false leaders and false deities] and believes in Allah, then, he has grasped the most trustworthy handhold that will never break. And Allah is All-Hearer, All-Knower. Allah is the 'Wali' [Protector or Guardian] of those who believe. He brings them out from darkness into light. But as for those who disbelieve, their "Auliya" [supporters and helpers] are 'Taghut' [false deities and false leaders], they bring them out from light into darkness. Those are the dwellers of Fire, and they will abide therein forever. (Qur'an, Surah 2, 256-257)

The Holy Bible also states: 'For it is written, As I live, saith the Lord, every knee shall bow to me, and every tongue shall confess to God. So then everyone... shall give account of himself to God. Let us not therefore judge one another anymore...' (Romans 14:11-13). These two verses from the Holy Qur'an and the Holy Bible tend to come out clearly that the principles of obeying 'onto you your religion and onto me my religion' can help to make the world a better place for the human race. Another example is the mode of dress that is similar across the religions. Hijab as a mode of dressing is influenced by a religious culture which provides symbolic interaction. Muslim women and Christian Nuns wear Hijabs to symbolise their faith and religion practice. Symbolic interaction is a process where an individual tries to anticipate an opponent's move so as to adjust his own behaviour accordingly (Mead 1934). The theory also contends that interactions among people are most likely to occur if all participants feel they are profiting from the relationship (Schaefer and Lamm 1989). For instance, it can be rightly stated that the understanding and bonding amongst the CAN members in Nigeria have somehow assisted them to checkmate the JNI Islamic conversion campaign and the differences within their various denominations.

\section{IMPACT ON NIGERIAN MILITARY INSTITUTIONS}

As the military performs its honour and duty for the common good and for union survival, soldiers will always respect the Constitutional provision, particularly for the protection of the human right to freedom of religion practice and freedom of association. Freedom does not come cheap and it cannot be taken for granted. Maturity of any nation can be seen from the people's interest in learning the fundamentals of the Constitution, her democratic practice and her ability to convert such learning experiences into 'not merely agreements but...sound and fair agreements' (Obama 2006, 112). Understanding the Constitution is a part of regular military training and it needs to be extended to civilian educational outfits to help them appreciate why 
secularism, as entrenched in the Constitution, must not be violated in the spirit of national security.

Understandably, in the political sphere politics can be mixed with religion, but the professional military does not ignore the historical fact that the bullet never discriminates who to kill in respect of religious inclination, and therefore allows her personnel to practise the religion of their choice, thereby keeping faith to religion secularity in Nigeria. This is a part of the military bonding process too. The military table of organisations also includes Chaplain Services which cater for Muslims, Catholics and Protestants of all ranks, meaning commissioned officers and soldiers. As people are recruited into service, each individual is allowed to profess and practise his/her chosen religion. On every Friday of the week at 12 noon, the Muslims are allowed to go for their congregational Friday (Jumaat) prayers, while the Christians go for Bible reading. However, Sundays are free to both Christians and Muslims not on duty, who are free to go for either worship or rest. Those who die in service are laid to rest according to their religion and faith. As of date the military does not have a Chaplain section to cater for traditional religion worshippers, since there is no written doctrine. However, for oath-taking purposes, on enlistment of such soldiers or for the commissioning of officers into the armed forces, they are allowed to use a bayonet in the place of the Holy Bible or Qur'an. By so doing, all members of the armed forces are given equal treatment in all religious matters.

In this manner military ethos, discipline and values are maintained. The idea of duplicating religious outfits for businesses, as a way of accumulation of wealth found in the civilian setting for fighting spiritual wars, are alien to the military forces. In her spiritual warfare manual, Brown $(1987,123)$ cautioned Christians to be careful not to blindly follow any teachings they hear, otherwise they themselves will fall into the trap of practising witchcraft. This same caution also needs to be extended to the Muslim faithful in the face of self-labelling Islamic terrorist groups, whose ideology is completely at variance with the teachings and practice of Islam; a religion of peace.

\section{INFLUENCE OF EDUCATION AND SECULARISM}

In the 50s and 60s there were many religious educational institutions, and very few Federal educational institutions. By the mid-70s, there was widespread government takeover of religious schools in Nigeria. Some people believe that Nigeria would have become a religious state (non-secular state) if government had not totally taken over education institutions and religious bodies then. Yet, there are some others who believe that the takeover of schools was a great mistake ${ }^{2}$ and a violation of the principle of secularism entrenched in the Constitution. This latter opinion became the basis of agitation for schools' return to previous owners in line with the adoption 
of the 1999 Constitution of the Federal Republic of Nigeria, in which Section 38(2) says:

No person attending any place of education shall be required to receive religious instruction or to take part in or attend any religious ceremony or observance if such instruction, ceremony or observance relates to a religion other than his own or a religion not approved by his parent or guardian.

The situation was further reinforced by Section 38(3), which expresses disapproval of a situation that will infringe on anybody's religious belief or jeopardise it. Obviously, the need to respect the fundamental human rights of the individual or group of citizens, tops the reasons why people clamour for the return of formerly taken over religious and private educational institutions. This position was further driven home in Section 38(3) that says:

No religious community or denomination shall be prevented from providing religious instruction for pupils of that community or denomination in any place of education maintained wholly by that community or denomination. (Amended Federal Republic of Nigeria Constitution 1999, 44)

By these provisions in the Constitution, education in Nigeria automatically fell into the concurrent list as stated in the Constitution. This means that governance at Federal, state and local government levels, as well as the private sector of the economy and also non-governmental agencies, have roles to play in moving education forward at policy formulation level and in financing it. So, it was easy to return such takeover schools to private and religious bodies, as there had been no compensation from Federal Government during initial forced acquisition. This situation further opened doors for religious, private or community organisations (who meet the minimum standards set forth by the Federal Government for the establishment of private schools) to apply and set up schools, thereby closing the gate of government monopoly on providing all-round education to Nigerians. In particular, the Constitution allows religious denominations to maintain wholly educational institutions for pupils of the community to spread their religious cultural diversity. The impact has been great in creating more educational institutions for the rapidly growing population that would have otherwise been illiterate.

Government set up an Inter-religious Council as an avenue for interaction with stakeholders in order to effectively moderate the enforcement of secularity, and to advise the President on ways and means of alleviating violence amongst religious communities. Similarly, Muslim and Christian Pilgrims' Boards were set up too. Amidst these orderly forms of control, the tax payers' money is directly being spent on religious affairs, contrary to the law of the land that forbids the government from becoming involved in such affairs. When viewed from another angle, such 
intervention is of national interest and also a way of providing a level playground for every citizen to help in checking the numerous preachers now surreptitiously downplaying the sanctions of heaven in favour of 'a new-fangled theology of prosperity and revelry' (Maduekwe 2005, 164). There have been too many religious riots in Nigeria (Yesufu 2007; Zahradeen 1989). According to a Federal Government $(1981,15)$ report, there were more than 33 violent religious riots before the Kano religious riot of 1980. Kukah $(1993,154)$ notes that before the Kano religious riot there was the Kaduna State religious riot.

\section{EXTERNAL FACTOR INFLUENCE IN UNDERMINING SECULARISM IN NIGERIA}

According to Kukah $(1993,42)$, international connection is easily noticed due to the flow of Arab money for years for the propagation of Islam in all its forms in northern Nigeria. Sharia debate in the Constitutional Assembly of 1988, and its subsequent adoption in year 2000 in some states in the north, took place with total disregard to the constitutional provision of separation of religion from state. Similarly, Nigeria's membership of the Organisation of Islamic Countries (OIC) in 1986 made many Nigerians to question the secularity of the Federal Republic of Nigeria. The pilgrimage ceiling of 20000 Muslims and 1300 Christians by the Buhari administration in the eighties, was also seen as another threat to non-Islamic religion (West Africa 6.5.85, 1094). In other words, these experiences have made people to be edgy about religious issues. The resulting volatility led to frequent crises capable of destroying any nation's peace, human rights and good governance. For instance, the African continent is witnessing human tragedy in the Central African Republic where citizens of one religious denomination are destroying citizens of other religious faith (Human Rights Watch 2014).

From the above we can deduce that Arab nations' constant grant to promote the Islamic religion, as well as the enhancement of the northern regions of Nigeria's political relevance and retrieval of power from the southern regions (Akinkuotu $2000,12-16)$ may well be regarded as a manipulation strategy for detonating religious riot time bombs and political crises in Nigeria. Obviously, such monies might have equally made it possible for radical believers to be funded fully in some states in Nigeria. A good example for such avenue is the 'Islam in Africa Organisation (IAO)' which has Nigerian statute with a goal to winning the whole of Africa for Islam. According to the U.S. Department of State (2008), the IAO is being funded by some government organisations in Nigeria. Interestingly, the IAO is said to be an initiative of the Organisation of Islamic Countries (OIC), which Nigeria joined in 1986. Those actions also constitute lack of respect for the secularism status of the state. Similarly, 
the situation is further complicated by the lack of political will or constitutional courts to prosecute offenders who go against the law on secularism.

\section{CONCLUDING REMARKS}

The impact of religion in a secular state seems to have played out negatively in Nigeria, as politics and religion are mixed in the attempt to gain political hold on the population. For a very long time, religion has been used by the (Nigerian) oligarchy as its main weapon to hold on to power (Kukah 1993). The situation seems to be gradually changing with the waning of oligarchy's influence over citizens in specific states. Of note is that, whenever an attempt is made to explore the leadership gap created by the waning situation at curbing influential resistance of government or members of religious groups, it generates a state of insecurity. However, the creation of JNI by the Muslims and CAN by the Christians has provided strong impact in the continued interaction and efforts at gaining social positions within the social system in Nigeria. In dialogue with government on religious matters, the two associations were found to readily provide credible leadership on religious affairs in Nigeria without rigid ideology regarding issues of ethnicity and race.

\section{NOTES}

1. These figures are derived from a population growth rate of 2.83 per cent based on 1991 census and various household survey reports and population estimates. See, National Bureau of Statistics $(2005,5)$ June.

2. Archbishop Okoh. 2010. Federal Government Take-over of schools in the 70s, a great mistake. He did not only describe it as a great mistake, but noted it to be 'a wrong step in the wrong direction' as it puts the education sector 'in a comatose state'. http:// community.vanguardngr.com/forum/topics/federal-government-take-over (accessed on 7 January 2016).

\section{REFERENCES}

African Development Bank. 2014. AfDB Statistics Pocketbook 2014. Tunis, Tunisia: Statistics Department, Volume XVI: 97.

Akinkuotu, A. 2000. Defusing the Sharia bomb, TELL, No.16, April 17: 12-16.

Blau, P.M. 1969. Exchange of social rewards, In Sociological theory: A book of readings ( $3^{\text {rd }}$ edition). Edited by L.A. Coser and B. Rosenberg. London: The Macmillan Company CollierMacmillan.

Brown, R. 1987; 1997. Prepare for war. Lagos: Bisso Nigeria.

Coser, L.A. and Rosenberg, B. (eds). 1969. Sociological theory: A book of readings ( $3^{\text {rd }}$ edition). London: The Macmillan Company Collier-Macmillan. 
Danbatta, M. 1956. Missionaries condemned at Muslim Congress. Nigerian Citizen, 20.

Durkheim 1915. The elementary forms of the religious life. London: Allen \& Unwin.

Federal Government of Nigeria. 1999. Original Gazette amended Constitution of the Federal Republic of Nigeria. Lagos, Nigeria: Federal Government Printer, No. 20, Vol.98, 7 March, 2011.

Federal Government of Nigeria. 1981. Report of tribunal of inquiry on Kano disturbance. Lagos: Federal Government Press.

Free Encyclopidia, https://en.wikipedia.org/wiki/Interactionism-Wikipedia (accessed on 15 June 2016.

Human Rights Watch. 2014. Hundreds of Muslim residents in western parts of the Central African Republic (C.A.R.) are trapped in enclaves in deplorable conditions http://www.hrw. org/news/2014/12/22/central-african-republic-muslims-trapped-enclaves (accessed on 12 January 2015).

Kukah, M.H. 1993. Religion Politics and Power in northern Nigeria. Ibadan: Spectrum Books.

Mathew, O. 2005. Echoes of the future. In Raising the bar: Selected speeches and writings of Ojo Maduekwe. Edited by C. Uche Ugboajah. Ibadan: Spectrum Books.

Maykovick, M.K. 1980. Sociological theories. In Medical sociology. Shermen Orks: Alfred Publishers, 37-60.

Mead, G.H. 1934. Play the game, and the generalized other. In Sociological theory: A book of readings ( $3^{\text {rd }}$ edition). Edited by L.A. Coser and B. Rosenberg. London: The Macmillan Company Collier-Macmillan, 273-282.

National Bureau of Statistics. 2005. The Nigerian statistical fact sheets on economic and social development. Abuja: National Bureau of Statistics (June).

Obama, B. 2006. The audacity of hope: Thoughts on reclaiming the American dream. New York: Vintage Books.

Schaefer, R.T. and Lamm, R.P. 1989. Sociology (3 ${ }^{\text {rd }}$ edition). New York: MacGraw-Hill.

The Noble Qur'an. English translation of the meanings and commentary. Madinah: King Fahd Glorious Qur'an Printing Complex.

The Holy Bible, King James version, with words of Christ in red, maps, and selected help to Bible Study. Nashville, Tennessee: Holman Bible Publishers.

U.S. Department of State Diplomacy in Action. 2008. International religious freedom report 2008 www.state.gov./j/drl/rls/irf/2008/108385.htm (accessed on 13 November 2014).

Usman, B. 1987. The manipulation of religion in Nigeria 1977-1987. Kaduna: Vanguard Publishers.

Yesufu M.L. 2007. The 2001 Jos Conflict and its impact on women and children. In Women, children and internal conflict in Nigeria. Edited by Okechukwu Ibeanu and J.G. Sanda. Ibadan: HEBN Publishers.

Zahradeen, N.B. 1989. The Maitatsine Saga. Zaria: Hudahuda Publishing. 